\title{
Integration of educational content of school discipline "Social Science" in expanding information space
}

\author{
Anna Y.Lazebnikova ${ }^{1, *}$, and Tatiana V.Koval ${ }^{1}$ \\ ${ }^{1}$ ISED RAE, Centre of social and Liberal Education, 105062, Moscow, Russia
}

\begin{abstract}
The article focuses on the representation and analysis of the most significant features of "Social Studies" as an integrated discipline comparing with separate school subjects. The conclusions are based on the research of expectations and demands of students (9 - 11 grades) as subjects of educational process. The perspectives of interdisciplinary approach in social sciences are presented as the way to rise effectiveness of students socialization in modern information society.
\end{abstract}

\section{Why is it important to maintain an integrated discipline?}

Fundamental contradiction of modernity is the growing disparity between avalanche of information flow and the human ability to perceive and use it. The most acute forms of contradiction acquired in the school system. Desire to include new knowledge (that is constantly produced by science) in the content of education, as well as to reflect the emerging topical issues leads to an increase in the volume of subjects. Consequences are overload of students and decline in efficiency of training.

Different ways to soften the contradiction were discussed in 1980s. The task to offload educational content was delivered, freeing him from the "non-binding and secondary material" [1]. However, scientists and methodologists have not reached a consensus on what educational material should be classified as basic and important. The same problem arose in the beginning of XXI century when "education minimum", "fundamental core", "basic level" in education was to be defined. The developers of the Federal state education standards (FSES, 2012) fully refused to solve the problem of the content of education and shifted to its results.

Another way to solve the problem was inclusion in the school curriculum so-called integrated subjects "covering" a number of related cognitive domains in a same academic discipline. Social studies were among integrated subjects. It was in our schools for more than half a century. In the early 1990s the content of this subject [2] and its position in the curricula [3] was radically changed.

In 2014 needs and requests of students in social science issues were researched. The first group of respondents were graduates from 9th grade, 139 respondents, the second group were high school students (10th-11th grades), 198 respondents were from Mos- cow, Belgorod and the Moscow region [4]. Compare the topics which are in the focus of students' attention (Fig. 1). Both groups show interests in the issues related to relationships of an individual and society, interpersonal communication, family relations, youth culture. A lot of ninth-graders $(70 \%)$ expressed interest in philosophical issues. Note that these units would be lost in case of replacement of the integrated subject by the "Economics" and "Law".

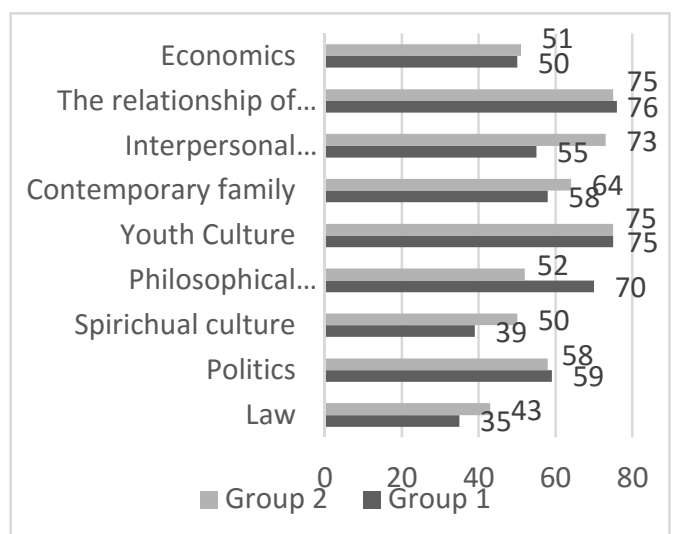

Fig. 1. Topics caused interest of students, \% of respondents in both groups Integrated Social Studies allows correlation of phenomena related to different spheres of society, comprehensively analyze complex phenomena of social life, social institutions (e.g., a family is seen as a component of the social structure and as significant for human small group, and as a household involved in economic relations).

The problem of socialization of the younger generation has a special importance for teenagers. We solve it when discuss the key characteristics of modern society, opportunities and limitations which society creates for new generations. Teenagers are becoming more independent in decision-making on important issues, connected with social factors. Though the integrated subject "covers" all social space (economic development,

\footnotetext{
* Corresponding author: alazebnikova@mail.ru
} 
cultural codes, social hierarchies and political processes) it gives opportunities for students to present themselves in new social roles; to discuss various strategies and models of behavior; to reflect their own preferences and social stereotypes

\section{Internet as a source of information}

It is difficult to imagine the modern student, who would not have turned to the Internet resources. Our research examines which sources of information respondents prefer to study social sciences at home. The vast majority of respondents (75\% in the 1 -st and $97 \%$ in the 2-nd group) use nternet resources, in particular for homework (Fig. 2). This shows development of computer technologies, their penetration in the education sphere (at least in the areas where the survey was conducted).

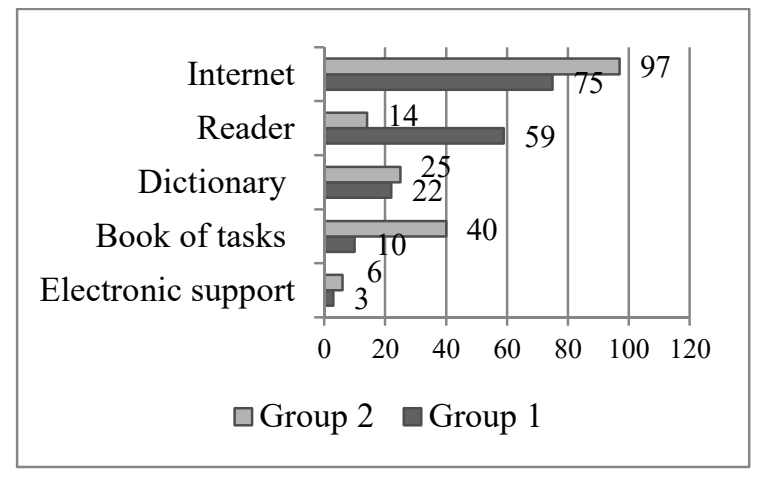

Fig. 2. "Use when do my homework", \% of respondents in both groups

The data in the table 1 show the kind of information that attracts attention of students.

Table 1. Internet search

\begin{tabular}{|l|l|l|l|}
\hline & Type of information & $\begin{array}{l}\text { Group } \\
1, \%\end{array}$ & $\begin{array}{l}\text { Group } \\
2, \%\end{array}$ \\
\hline 1 & $\begin{array}{l}\text { Scientific articles } \\
\text { (monographs) }\end{array}$ & 33 & 38 \\
\hline 2 & Lectures & 22 & 23 \\
\hline 3 & Presentations & 11 & 19 \\
\hline 4 & Essays & 14 & 21 \\
\hline 5 & $\begin{array}{l}\text { Answers to specific } \\
\text { questions }\end{array}$ & 71 & 76 \\
\hline 6 & Homeworks & 13 & 11 \\
\hline
\end{tabular}

The first at the number of elections is "answers to specific questions" position, reflected the real role of the Internet in self-sustained students' homework. The "ready-made" essays, presentations, etc. are also popular to a much lesser extent. Appeal to the scientific publications and lectures of experts provides an opportunity to evaluate the proportion of respondents interested in a deep study of the subject/ It is from $22 \%$ to $42 \%$.

In general, the research reveals that students are interested in various aspects of social sciences, which are widely presented in the integrated subject. Thus the demand of students correlates with the main option of Social Studies: to create conditions for personal growth and successful socialization. The textbooks should better reflect students' interest in philosophical problems. It is important for teachers not to overestimate desire of students to use the Internet: there is a demand of "ready-made" answers. So a teacher should encourage the usage of computer technologies to support analytical skills, to develop critical thinking and creative abilities of students.

\section{Priorities for selection of content: theoretical knowledge and problems of social reality}

If the theoretical knowledge is the focus of school education, it is advisable to introduce separate subjects "Economics", "Political Science", "Law", and so on. Following the logic of science, they would build the theoretical foundation, which later will be the basis of professional training in this area. In turn, the review of processes and real problems of social reality also relies on some theoretical basis: key concepts, guiding principles, a number of common positions and conclusions. However, they are not the main objects of study, but only tools. Some authors in the 1990-s offered training programs, which were based on typical problems of social life, and theoretical information was used "situationally". The priorities (theoretical knowledge or social reality) will determine purpose and nature of final certification tasks. In the first case students concentrate on theories and concepts, in the second - on ability to analyze and evaluate the phenomena of social life, using theoretical knowledge.

The risk of the first approach is related to the fact that society is not considered as a whole phenomenon and "disappears" as an independent object of research. In addition, the study of a single subject in the logic of scientific knowledge represents a specific challenge for today's teenagers. In the second case there is a risk to lose the ability to theoretical understanding of social reality. Facts of modern social life actually serve to illustrate theories, narrowing the information about social reality.

Analysis of teaching practice shows the predominance of the first approach. The textbooks of "Economics" and "Law" in our school correlate with those in higher school and are arranged in the logic of scientific knowledge. Among them we have successes: there are books and manuals that clearly present the theoretical fundament of a scientific discipline for the students. Not so with the textbooks, built on analysis of social reality. The creation of these textbooks is more complex task, than the popular theoretical sketches of scientific issues. We believe that the creation of such textbooks would be a step forward to development of social studies at school. The school would considerably strengthen its contribution to the socialization of young people, if gives the answers to the questions that really care all students, and not only those who are preparing for the higher school. 
We assume that an appropriate balance can be achieved in the integrated course of social science, which includes concepts and theories. What is more: there is an opportunity for formation of values and development of skills in accordance with age and psychological characteristics of students. The demands of students as the main subjects of the educational process would be more effectively satisfy in the framework of the integrated course.

\section{Entering a new level of integration}

The focus of the FSES is to achieve certain results, including interdisciplinary ("metasubject") ones. To reach this goal school requires a new level of integration of subjects. The Center of Social and Humanitarian education ISRO RAO investigates the effective ways to achieve interdisciplinary results on the basis of school disciplines History, Economic and Social geography, Social Studies. Taking into account all the existing differences in understanding of interdisciplinary approach we believe that

- concrete discipline still remains the basic unit of education content and the ground on which interdisciplinary approach is built;

- interdisciplinary approach appears in both components - content and activity;

- interdisciplinary content is constructed around the so-called interdisciplinary concepts; research objectives are to identify these concepts and to analyze their "parameters" (volume, interpretation, aspects of meaningful context); examine their nowadays usage in all disciplines mentioned; suggest the interdisciplinary approaches for the formation of these concepts and for their usage;
- interdisciplinary activity is associated with the formation of so called "universal educational actions"; research objectives are to develop and test new models of tasks to encourage intellectual activity (comparison, classification, transfer from one symbol system to another, interpretation, etc..), as well as complex competences (semantic reading, working with various sources of social information).

The processes of integration of educational contents gaining strength in education promote solution of a number of tasks facing today school, including also those which are generated by calls of information society.

\section{References}

1. Models and structures of school education: national and international experience: monograph, (Nestor-History, Moskva-Sankt-Peterburg, 2012) [In Rus]

2. A.Y. Lazebnikova, Sovremennoe shkol'noe obshchestvoznanie, (Shkola-Press, Moskva, 2000) [In Rus]

3. L.N. Bogolyubov, Obshchestvoznanie v sovremennoi shkole: aktual'nye voprosy teorii i metodiki (Nestor - Istoriya, Moskva-Sankt-Peterburg, 2013) [In Rus]

4. T.V. Koval', Prepodavanie istorii i obshchestvoznaniya v shkole, 1 (2015) [In Rus] 